\title{
THE TIME OF WEANING AND ITS EFFECTS ON REPRODUCTIVE FUNCTION
}

\author{
M.A. VARLEY \\ Department of Applied Nutrition, Rowett Research Institute, Aberdeen, UK
}

Conventional systems of pig production include a lactation length of six to eight weeks duration followed by a quick return to oestrus and ovulation. The reproductive life of the sow consists therefore of two complete production cycles in one twelve-month period. Throughout the 1970s, many producers dispensed with this hitherto acceptable system in favour of weaning piglets from the sow at a much earlier age. The reasons for this are many and varied. By weaning earlier the average time from one farrowing to the next is reduced and hence each sow has more than two reproductive cycles in one year. For approximately the same input of sow feed a significant increase in the number of weaners is produced per sow per year. As a result of this reasoning a number of quite different systems have evolved and these include 35-day weaning, 21-day weaning and 10-day weaning. Each of these systems is associated with markedly different reproductive function and it is the purpose of this chapter to review the considerable amount of recent work in this area and to examine how weaning age influences many of the parameters used to assess reproductive efficiency.

\section{The interval from weaning to conception}

At the end of a 6-8 week lactation the sow may have already escaped, at least partially, from the known inhibition of hypothalamic and pituitary function induced by the suckling stimulus. Gonadotrophins have been produced and stored in the anterior pituitary gland and at weaning a rapid follicular phase results in oestrus and ovulation some four or five days later. Reducing lactation length below 42 days may leave the hypothalamic-pituitary axis unable to respond in exactly the same way at weaning and therefore sows may take longer to return to oestrus and the variability of the interval from weaning to oestrus increases. This has been shown in a number of studies (Aumaitre, 1972; te Brake, 1972; Dyrendahl et al., 1958; Moody and Speer, 1971; Self and Grummer, 1958; Van der Heyde, 1972; Svajgr et al., 1974; Cole, Varley and Hughes, 1975; Varley and Cole, 1976a). The relationship between lactation length and the interval from weaning to oestrus is illustrated in Figure 22.1. It can be seen that as lactation length is reduced the interval from weaning to oestrus rises 


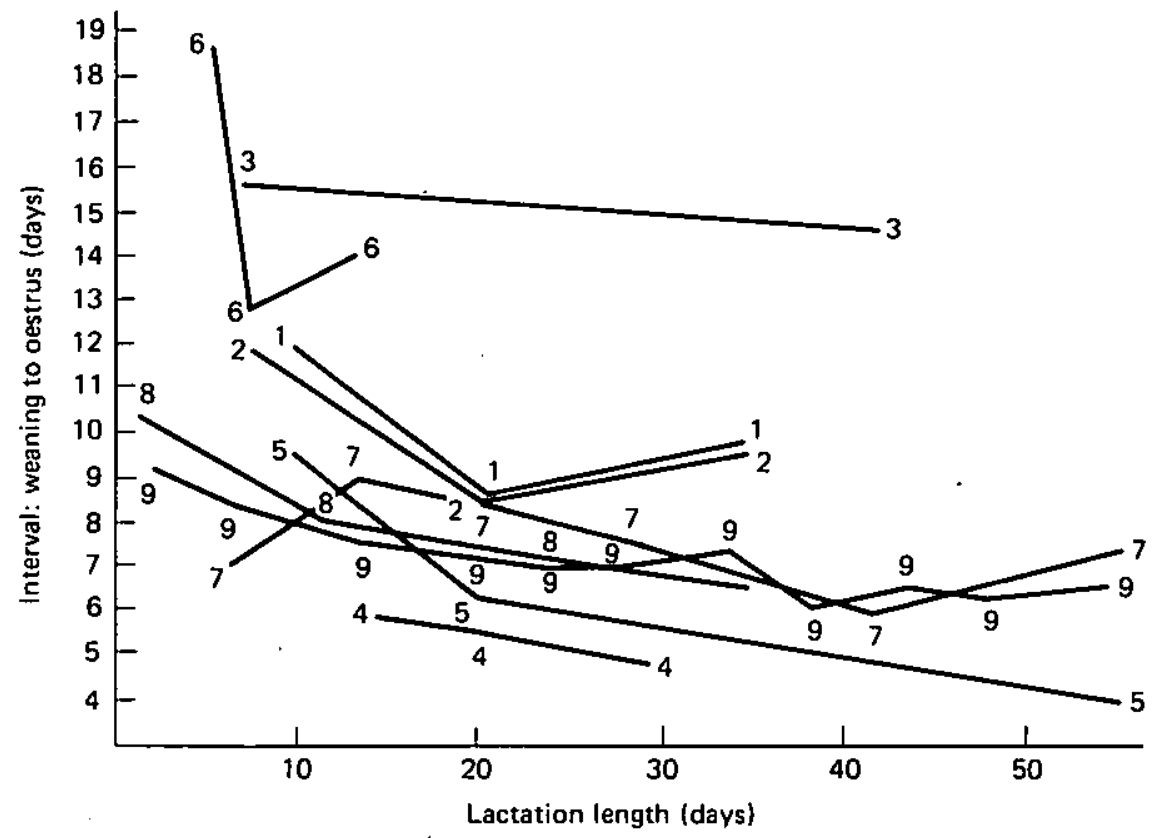

Figure 22.1 The effect of lactation length on the interval from weaning to oestrus. Numbers refer to references as follows: 1. Aumaitre (1972); 2 . Aumaitre and Rettigliati (1972); 3. te Brake (1972); 4. Moody and Speer (1971); 5. Self and Grummer (1958); 6. Van der Heyde (1972); 7. Puyaoan and Castillo (1963); 8. Svajgr et al. (1974); 9. Smidt, Scheven and Steinbach (1965)

significantly. When weaning age is three weeks the average interval from weaning to oestrus appears to be at a value of around seven days. When weaning age is further reduced to ten days the average interval rises again to around nine days. This relationship has beén established numerically by Cole, Varley and Hughes (1975) who found that:

$$
\log Y=0.931-0.0077 X
$$

where $Y=$ the interval from weaning to oestrus in days

$X=$ lactation length in days

In a series of experiments the same workers compared very early weaned sows with sows weaned after a 42-day lactation and found that both the interval from weaning to oestrus and its variability increased markedly as lactation length dropped below 21 days (see Table 22.1).

Table 22.1 THE EFFECT OF LACTATION LENGTH ON THE MEAN AND STANDARD DEVIATION OF THE INTERVAL FROM WEANING TO OESTRUS

\begin{tabular}{llllllll}
\hline & \multicolumn{6}{c}{ Lactation length (days) } \\
\cline { 2 - 7 } Authors & \multicolumn{2}{c}{$7-10$} & \multicolumn{2}{c}{21} & \multicolumn{2}{c}{42} \\
Mean & SD & Mean & $S D$ & Mean & $S D$ \\
\hline Varley and Cole (1976a) & 8.2 & 2.8 & - & - & 4.5 & 0.5 \\
Varley and Cole (1976b) & 8.2 & 1.6 & 7.2 & 3.3 & 5.0 & 0.5 \\
\hline
\end{tabular}


There are many diverse factors that can affect the interval from weaning to oestrus and these have been reviewed in detail elsewhere (Varley, 1976; Hughes and Varley, 1980). Briefly they can be listed as: genotype, age, parity and season. Plane of nutrition plays a negligible role in this respect (Brooks et al., 1975; Clark et al., 1972; Dyck, 1972).

In sows weaned following conventional lactation lengths, pituitary FSH (follicle stimulating hormone) rises very little in the immediate postweaning period but pituitary $\mathrm{LH}$ (luteinizing hormone) rises significantly (Crighton, 1967). Increased production and storage of LH must therefore characterize the sow's post-weaning endocrine status. Peripheral LH activity is not seen until just prior to ovulation (Parlow, Anderson and Melampy, 1964). FSH therefore must be undergoing very rapid production and release from the pituitary in view of the rapid growth in the number and size of follicles on the ovaries at this time. Oestrus and ovulation subsequently occur due to the surge of oestrogen produced from the follicles which induces LH release from the pituitary under the permissive influence of pulsatile GnRH (gonadotrophin releasing hormone) (Edwards and Foxcroft, personal communication; Knobil, 1980).

This sequence of events is disturbed in some way by reducing the lactation length. If the pulsatile pattern of $\mathrm{GnRH}$ release is the same in the pig as has been demonstrated in other species (Knobil, 1980), then the suckling stimulus in early lactation will result in an inhibition of production and release of the hormone into the pituitary portal circulation. The sow therefore remains in anoestrus completely in early lactation. As the lactation proceeds beyond the 21-day stage the inhibitory effect of the suckling stimulus on the hypothalamic production of GnRH diminishes. This is clearly indicated by the fact that many sows in the late part of a 42-56 day lactation will either show spontaneous oestrus and ovulation whilst still lactating or can be induced to show a fertile heat by a variety of husbandry techniques (Burger, 1952; Smith, 1961; Rowlinson and Bryant, 1974). Pulsatile or episodic release of GnRH must therefore begin again at some point in mid lactation. By weaning much earlier than 21 days the

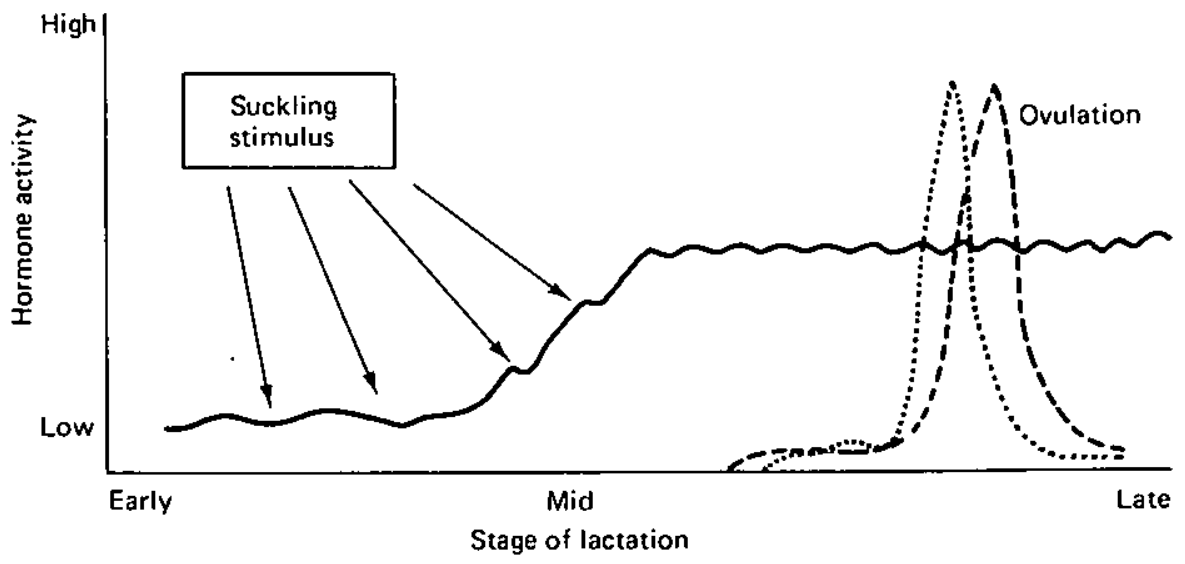

Figure 22.2. A diagrammatic representation of the sow's gradual escape from the lactational anoestrous condition. — pulsatile $\mathrm{GnRH} ; \cdots \cdots$ oestrogen; ---- gonadotrophins 
hypophyseal axis has not yet been 'primed' by both GnRH and the modulating influence of oestrogens acting via the negative feedback loop on the hypothalamus. The sow is therefore unable to show a rapid follicular phase and the return to oestrus and ovulation is significatnly delayed. Figure 22.2 gives a diagrammatic representation of this effect. It does seem that despite this effect, sows do still show a detectable heat after a 7-10 day lactation and the percentage of sows becoming anoestrous is similar to that seen in sows weaned after conventional lactation lengths (Varley and Cole, 1976a,b; Varley and Cole, 1978).

\section{Conception rate}

There is some doubt about the effect lactation length has on the ability of the sow to conceive at the first post-weaning oestrus. Aumaitre (1972) found that sows weaned after a 35-day lactation showed a conception rate of $97.6 \%$, whereas the figure for sows which were weaned at seven days was $86.0 \%$. te Brake (1972) observed a larger reduction in his study where sows weaned at 42 days had an overall conception rate of $79.2 \%$ compared to $53.3 \%$ for sows weaned at seven days. In contrast, Cole, Varley and Hughes (1975) and Varley and Cole (1976a) found no differences in either conception or farrowing rates for sows weaned after lactation lengths of 42 days or 10 days. Van der Heyde (1972) concluded that there is considerable between-farm variation in conception rates and that it should be possible to achieve the same conception rate for both very early weaning and conventional systems. He added that the apparent low conception rates on some farms were often associated with incorrect frequency and timing of insemination. It might be that on farms changing to earlier weaning, stockmen are not prepared for the modification of the interval from weaning to oestrus and do not time admission of the boar correctly.

\section{The effect of lactation length on prolificacy}

The ultimate prolificacy in terms of the number of viable piglets produced at parturition per litter is a function of ovulation rate, fertilization rate and the survival of embryos and foetuses. All of these factors could be associated with the previous lactation length and will be reviewed in turn.

\section{OVULATION RATE}

In the light of the endocrine disturbances between weaning and remating of sows subjected to very short lactations, a concomitant reduction in the number of ova shed at ovulation might also be expected. This would depend on the pattern and magnitude of the release of both FSH and LH from the pituitary. To date the peripheralgonadotrophins between weaning and remating have never been measured in early weaned sows. The effect of lactation length on ovulation rate however has been measured and the results are presented in Table 22.2 . 
Table 22.2 THE EFFECT OF LACTATION LENGTH ON OVULATION RATE

\begin{tabular}{lllllll}
\hline & \multicolumn{7}{c}{ Lactation length (days) } \\
\cline { 2 - 7 } Authors & 2 & $7-10$ & 13 & 21 & 35 & $42-56$ \\
\hline Self and Grummer (1958) & - & 12.8 & - & 15.2 & - & 16.6 \\
Svajgr et al. (1974) & 15.6 & - & 15.0 & 15.2 & 14.4 & - \\
Varley and Cole (1976b) & - & 15.7 & - & 17.1 & - & 15.1 \\
Varley and Cole (1978) & - & 15.3 & - & - & - & 15.1 \\
\hline
\end{tabular}

In 1958 Self and Grummer observed a large reduction in ovulation rate which approached significant proportions $(P<0.06)$. This has not been substantiated by more recent studies (Varley and Cole, 1976, 1978; Svajgr et al., 1974) where no differences were found in ovulation rate, as determined by corpora lutea counts, between sows weaned at 42 days and sows weaned at seven days.

\section{FERTILIZATION RATE}

Fertilization rate and its degree of association with the preceding lactation length has been the subject of a number of studies. Self and Grummer (1958) found that following 10,21 or 56-day lactations, fertilization rates were $93.4 \%, 90.6 \%$ and $98.1 \%$ respectively and the differences were non-significant. For lactation lengths of 2, 13, 24 and 35 days, Svajgr et al. (1974) obtained fertilization rates of $81.9 \%, 86.3 \%, 96.5 \%$ and $98 \%$ respectively. The latter authors attributed this result to two sows in the group weaned at two days and one in the 13-day group which showed complete absence of cleaved ova at day 3 post coitum. Where conception took place, fertilization rates for sows weaned after 2-10 day lactations were comparable with fertilization rates for sows weaned after a more conventional (i.e. longer) lactation length.

\section{EMBRYONIC SURVIVAL RATE}

Two studies have shown clearly that lactation length adversely affects the ability of embryos to survive the first three weeks of gestation. Varley and Cole (1976b) evaluated the embryonic survival rate at day 20 post coitum for sows which had previously lactated for either 7, 21 or 42 days. Survival rates in these sows were $59.2 \%, 63.9 \%$ and $81.7 \%$ respectively and these large differences were significant $(P<0.01)$. Similarly Svajgr et al. (1974) for lactation lengths of $2,13,24$ and 35 days found survival rates of $54.3 \%$, $70.7 \%, 71.6 \%$ and $79.5 \%$ respectively. Embryo loss is therefore considerable even for sows weaned after long lactations; one in five fertilized eggs which begin developing after mating are lost by the end of the third week of pregnancy (Wrathall, 1971). For the early weaned sow this loss increases to about two in five.

Losses can be ascribed to a large number of factors and can be separated into two parts; firstly, those losses occurring during blastulation and before implantation and secondly those occurring around the time of implantation
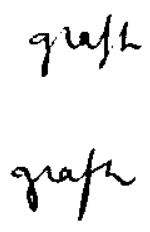
or soon after, as a result of malfunctions in the process of attachment (Wrathall, 1971). In order to study the relative importance of these two components, Varley and Cole (1978) slaughtered two groups of sows, weaned following either a 7- or a 42-day lactation, at nine days post coitum, i.e. just before the first attachment of the trophoblast to the endometrium. Survival of embryos for sows weaned at 7 and 42 days was $74.3 \%$ and $83.5 \%$ respectively but this difference was not significant. The authors concluded that although the trend was towards larger losses for the early weaned group, in the light of the earlier work where survival at day 20 post coitum (Varley and Cole, 1976b) was measured, the bulk of embryo losses for the early weaned sow was incurred at or around implantation.

\section{THE EFFECT OF LACTATION LENGTH ON LITTER SIZE}

The product of ovulation, fertilization and embryonic survival ultimately determines the size of the litter at the next parturition. Many studies have shown that the effect of high embryo losses for early weaned sows outlined above eventually result in a significantly reduced litter size (Aumaitre, 1972; Aumaitre and Rettigliati, 1972; Moody and Speer, 1971; Van der Heyde, 1972; Smidt et al. 1965; te Brake, 1972; Varley and Cole, 1976a; Cole, Varley and Hughes, 1974). This is illustrated in Figure 22.3.

A most exhaustive study has been carried out by Smidt, Scheven and Steinbach (1965) (Reference 5 in Figure 22.3). No significant difference was observed in this study in litter size of sows weaned after lactation

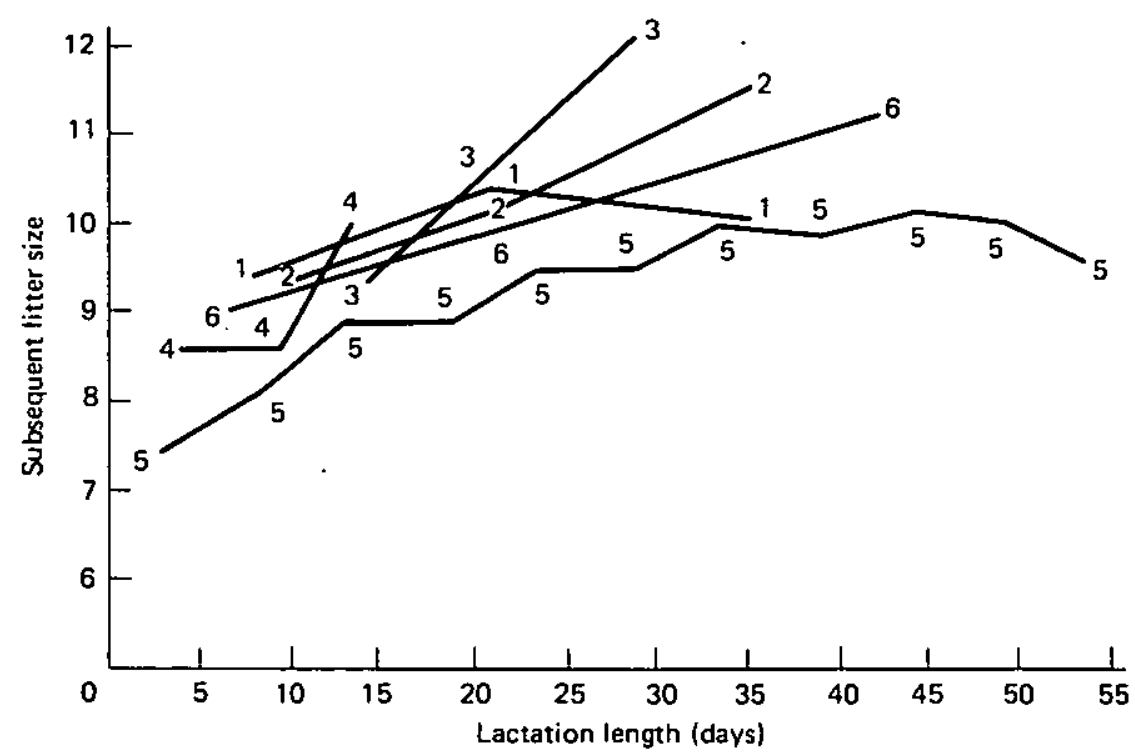

Figure 22.3 The effect of lactation length on subsequent litter size. Numbers refer to references as follows: 1. Aumaitre (1972);2. Aumaitre and Rettigliati (1972); 3. Moody and Speer (1971); 4. Van der Heyde (1972); 5. Smidt, Scheven and Steinbach (1965); 6. te Brake (1972) 
lengths of 56 days or 25 days. However, some authors (Aumaitre and Rettigliati, 1972; te Brake, 1972) have observed a difference in this respect and Varley (1979) has concluded that on average a small reduction in litter size will be observed with sows weaned after 21 -day lactations compared with sows weaned after 35-42 day lactations. Furthermore Varley (1979) estimated that the magnitude of this reduction is in the order of $0.1-0.2$. piglets per litter. There is however a large reduction in litter size as. lactation length is reduced below three weeks and Varley and Cole (1976a) concluded that a sow weaned at 7-10 days post partum would show a decrease of between 1.5 and 2.0 piglets per-litter at the next farrowing. This result is consonant with the findings on embryonic mortality (Varley and Cole, 1978).

The results of a series of experiments carried out at Nottingham University in the mid 1970s are presented schematically in Figure 22.4 and show the number of viable individuals per litter throughout the various, stages of gestation.

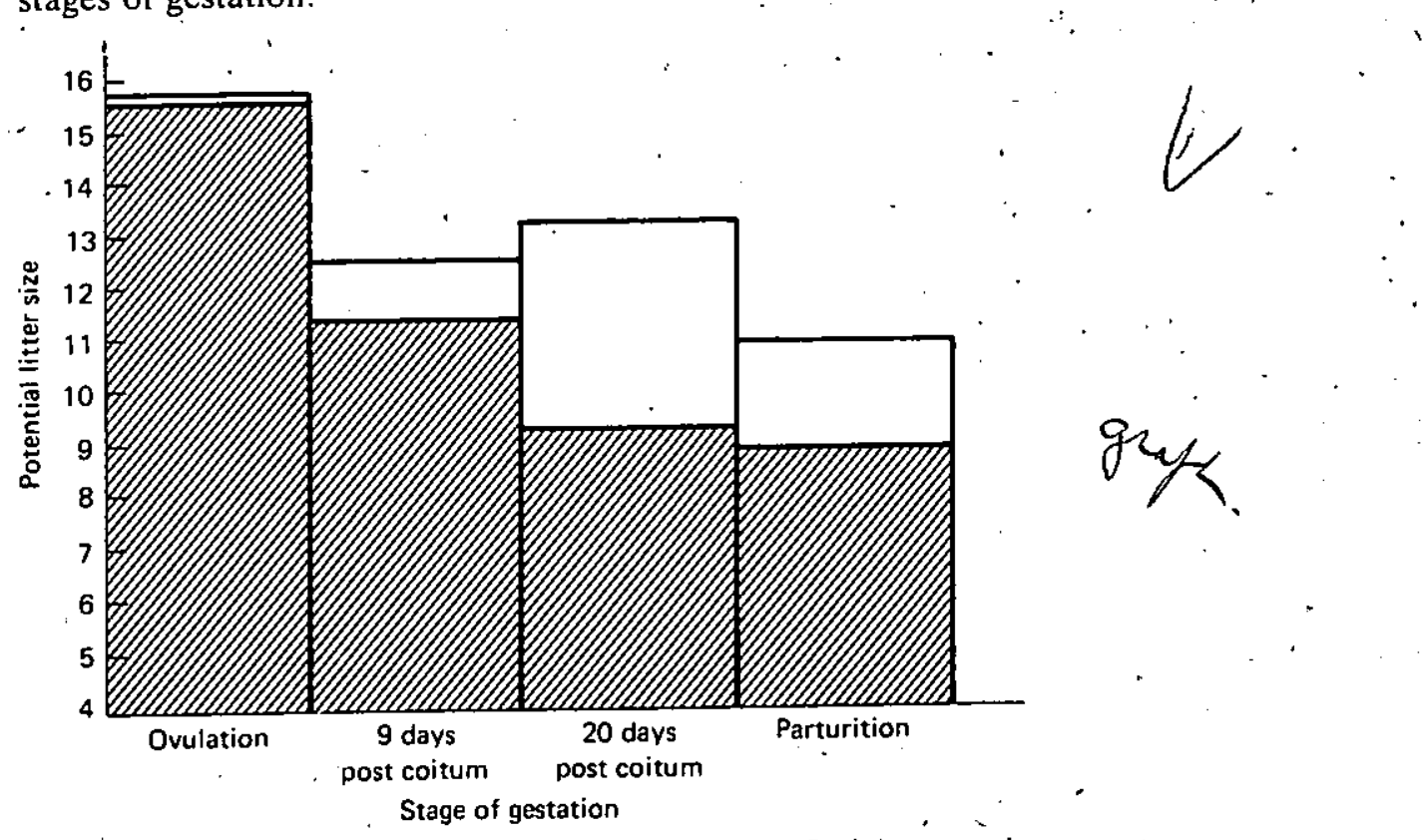

Figure 22.4 Litter size for the early weaned sow. Shaded area, 7-10 day weaned; open area, 42-day weaned

The small difference in litter size seen at day 9 post coitum is in'striking contrast to the large difference seen at day 20 post coitum. This difference is then reflected in the numbers born alive at parturition.

There have been reports from commercial practice (Pay, 1973; Looker, 1974) suggesting that very early weaning does not substantially reduce prolificacy. The large number of reports to the contrary however cannot be ignored and a commercial producer embarking on a programme of weaning earlier than three weeks must expect reduced prolificacy. Some of the differences between farms could be accounted for by variation in feeding systems but Varley and Cole (1976a) have observed that despite

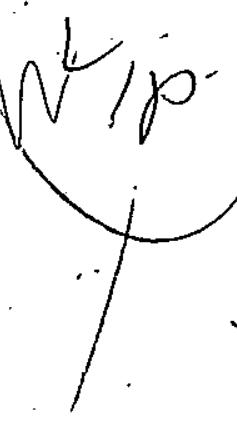


very large differences in feed intake throughout lactation and from weaning to remating, all sows weaned after 10-day lactations exhibited
reduced prolificacy.

An interesting observation was made by Walker et al. (1979) from the results of a large scale, long term study including 146 sows at two centres. These sows were allocated at random to one of three lactation lengths $(10$, 25 or 40 days) in their first parity. Each sow remained on the same treatment throughout the course of five parities and reproductive performance at each parity was recorded. The results are presented in Table 22.3.

Table 22.3 THE EFFECT OF LACTATION LENGTH AND PARITY ON THE NUMBER OF PIGLETS BORN ALIVE PER LITTER AND THE NUMBER OF

\begin{tabular}{|c|c|c|c|c|c|c|}
\hline \multirow[b]{3}{*}{ Parity } & \multicolumn{6}{|c|}{ Lactation length } \\
\hline & \multicolumn{2}{|c|}{10 (days) } & \multicolumn{2}{|c|}{25 (days) } & \multicolumn{2}{|c|}{40 (days) } \\
\hline & Born alive & Weaned & Born alive & Weaned & Born alive & Weaned \\
\hline $\begin{array}{l}1 \\
2 \\
3 \\
4 \\
5\end{array}$ & $\begin{array}{l}9.19 \\
9.01 \\
8.82 \\
8.62 \\
9.19 \\
\end{array}$ & $\begin{array}{l}8.40 \\
8.81 \\
8.31 \\
8.29 \\
8.64\end{array}$ & $\begin{array}{l}9.15 \\
9.28 \\
9.58 \\
9.65 \\
9.34 \\
\end{array}$ & $\begin{array}{l}8.24 \\
8.39 \\
8.77 \\
8.88 \\
8.26 \\
\end{array}$ & $\begin{array}{r}8.72 \\
8.36 \\
9.87 \\
11.31 \\
11.47 \\
\end{array}$ & $\begin{array}{l}8.20 \\
7.73 \\
9.33 \\
9.99 \\
9.75 \\
\end{array}$ \\
\hline
\end{tabular}

For the first two parities, there was little difference in either numbers born alive or numbers of piglets surviving to weaning. As the age and reproductive experience of the sow increased the sows weaned after long lactations produced significantly larger litters born alive when compared to sows weaned at 10 days. This large difference at birth however was not seen at weaning and the difference in numbers weaned between the 10-day weaned group and the 40-day group was not significant for parities 1-5.

This effect could well explain a proportion of the between-herd variation seen in practice. Few herds have identical age structure and newly established herds would not tend to notice changes in prolificacy as a result of earlier weaning, whereas long established herds particularly where culling rate had been low would experience a sharp drop in production of piglets born alive. Walker et al. (1979) suggested that the reason numbers were similar at weaning was that sows weaned at 40 days had very large numbers born alive which they were incapable of rearing throughout a long lactation. In contrast sows weaned at 10 days start off with fewer piglets at birth and then lose fewer in the short period of lactation. All of this strongly suggests that for all systems husbandry will be a major component influencing the final output of piglets per sow per year at weaning.

\section{Effect of lactation length on endocrine status}

Polge (1972) has speculated on possible differences in endocrine status between sows weaned after conventional lactation lengths and for very early weaned sows. He concluded from the work of Lauderdale et al. (1963) and Crighton (1967) that the concentration of LH in the pituitary 
gland increases much less in sows weaned within 1-11 days post partum than in sows weaned at 56 days post partum. In addition, FSH concentration in the pituitary dropped in sows weaned at eight weeks. This suggests that the very early weaned sow shows a much reduced pituitary response and this is in accord with the observed effect on the weaning to oestrus interval. Peters et al. (1969) and Kirkpatrick et al. (1965) both attempted to modify the endocrine balance of very early weaned sows by using exogenous applications of both FSH and pituitary extract. Sows could be induced to ovulate shortly after parturition but fertility was negligible. Moody and Speer (1971) have measured the luteal progesterone content of plasma at day 25 post coitum after lactation lengths of either 14,21 or 28 days and have found no differences.

Varley and Cole (1976b) measured plasma progesterone concentration from weaning to day 20 post coitum and concluded that differences might exist between sows weaned after different lactation lengths but in this study sows were bled only five times over the course of the experiment and therefore a definitive relationship could not be established.

In order to provide more data in this area, Varley, Atkinson and Ross (1981) have studied the plasma concentrations of progesterone and oestradiol-17 $\beta$ in sows weaned after lactation lengths of either 10 or 42 days. Sows were bled every second day from mating to day 26 post coitum. The plasma steroid concentrations are shown in Figure 22.5 and Figure 22.6.

The results illustrated in Figure 22.5 indicate the existence of a different pattern of progesterone secretion in early gestation between early and late weaned sows. Plasma progesterone between days 4 and 10 post coitum

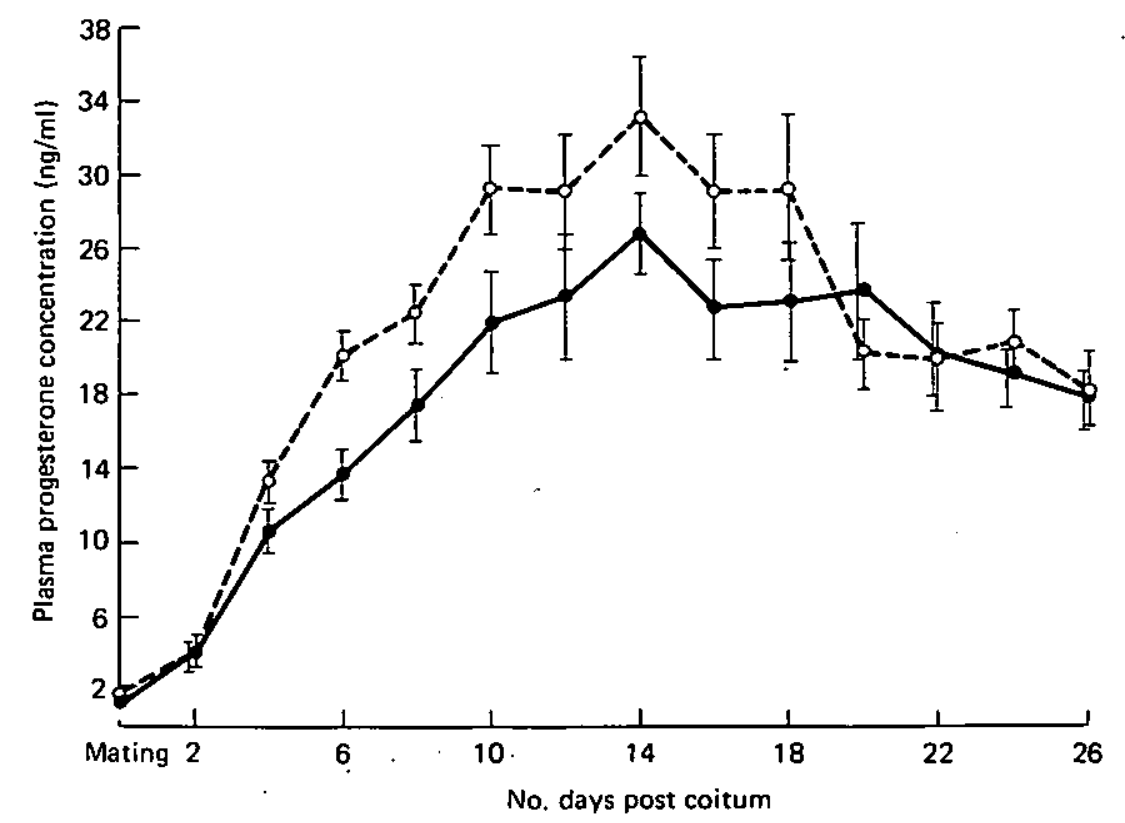

Figure 22.5 Variation in plasma progesterone concentration with number of days post coitum. O early weaned; control. (N.B. Control bars offset to left for clarity in some cases) 


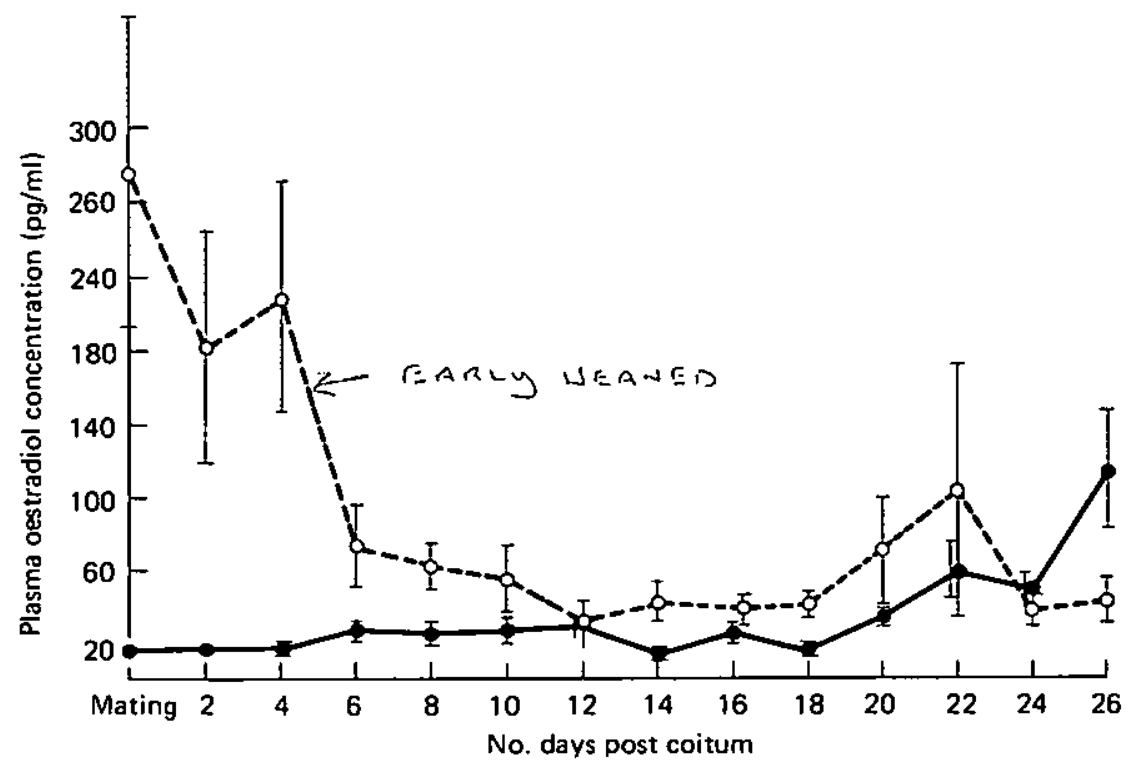

Figure 22.6 Variation in plasma oestradiol concentration with number of days post coitum. O. early weaned; control

increases significantly faster for early weaned sows. Part of this difference could result from chance differences in ovulation rate and unfortunately this was not measured. The two groups of sows nevertheless were of similar genotype, age, parity and liveweight and therefore minimal systematic bias of this kind was introduced in the experiment. It is more probable that the differences in progesterone were a direct reflection of the oestradiol concentrations seen in Figure 22.6. Early weaned sows showed a prolonged oestrogen surge during and after mating when compared to control sows weaned at 42 days.

The ramifications of these very aberrant steroid levels in early gestation in terms of embryonic survival were not measured and are the subject of a current study at the Rowett Institute. It is a matter of conjecture to implicate the observations shown in Figures 22.5 and 22.6 with embryonic survival but it seems likely that such steroid profiles could have a number of possible effects. Firstly, the rate of passage of fertilized eggs down the oviducts could be adversely affected (Day and Polge, 1968) and this almost certainly would result in eggs being lost prior to implantation. Varley and Cole (1978) observed mean differences of 1.3 embryos per litter at 9 days post coitum. Secondly, fertilized eggs experiencing abnormal tubal transport might subsequently be exposed to conditions within the uterine lumen in terms of secretory proteins with which they were not in synchrony. The net result would therefore be losses of embryos prior to implantation and then considerable loss during the implantation process itself.

It is now established that during the very early part of gestation in the pig the secretion of a number of different pregnancy specific proteins into both the uterine lumen and probably the maternal circulation takes place (Bazer et al., 1969; Murray and Grifo, 1976; Knight et al., 1974; Bashe et al., 1980; 
Etzel et al., 1978). This has also been reported in other species and comprehensive reviews on these have been published elsewhere (Beier, 1979; Klopper, 1979). The relative amounts of each of these proteins changes daily as gestation proceeds, presumably to service the rapidly changing needs of the growing embryo. This highlights the need to secure absolute synchrony in physiological status between embryo and uterine environment if maximum survival is to be attained. Some of these proteins may originate in the endometrium, others in the maternal liver and a plethora of names have been associated with them.

In the rabbit the terms blastokinin or uteroglobin have been used to name one protein fraction (Krishnan and Daniel, 1967; Beier and Maurer, 1975). Pregnancy associated proteins and progesterone induced proteins are other generic terms which have been used (Murray and Grifo, 1976; Klopper, 1979). This latter term refers to the fact that circulating progesterone activity plays a significant mediating role in the secretion of uterine proteins. Knight et al. (1974) established a dose response relationship between exogenous progesterone and porcine uterine protein secretion. The same group however (Knight, Bazer and Wallace, 1974) were unable to elucidate a relationship between induced uterine proteins and embryonic survival.

The function of these uterine proteins may not be one of simple egg nurture. It has been shown in many species including the pig that they have Whigh immunoreactivity (Etzel et al., 1978; McIntyre and Faulk, 1979; Roberts, 1977; Murray, Segerson and Brown, 1978). It has therefore been postulated that they act in a permissive way to allow implantation by suppressing the normal host/graft immune rejection mechanism at the interface between trophoblast and endometrium (Etzel et al., 1978; Murray, Segerson and Brown, 1978). Attempts have also been made to implicate other substances capable of effecting a similar suppression of the immune mechanism for the same purpose. One of these is $\alpha$-fetoprotein in the mouse (Murgita and Tomasi, 1975), the bovine (Smith et al., 1979), sheep (Lai et al., 1978) and woman (Hay et al., 1976).

If the integrated effects of these various immune suppressive factors is functioning at the correct intensity, then implantation is allowed to take place and the embryo implants onto the endometrium. Presumably the converse is also true, namely that if insufficient immune suppression is effected (i.e. insufficient uterine protein) then embryos fail to implant and die shortly after. In the case of the pig, it is possible that this delicate mechanism of immune acceptance or rejection acts as a natural selection process to cull a proportion of the high number of embryos (15-20) originally entering the uterus after fertilization. By disturbing the peripheral steroids as a result of very early weaning we may be shifting this delicate balance towards fewer embryos being able to overcome the less favourable uterine environment. It has been suggested (Bazer et al., 1969) that embryos 'compete' for an essential biochemical factor which may be uterine proteins, in order to achieve survival and further development. In this way the uterus may impose a ceiling on the number of offspring carried to term. It should be emphasized however that to date no causal relationship between progesterone induced proteins and the rate of survival of embryos has been elucidated (Knight $e t$ al., 1974) and the two appear to 


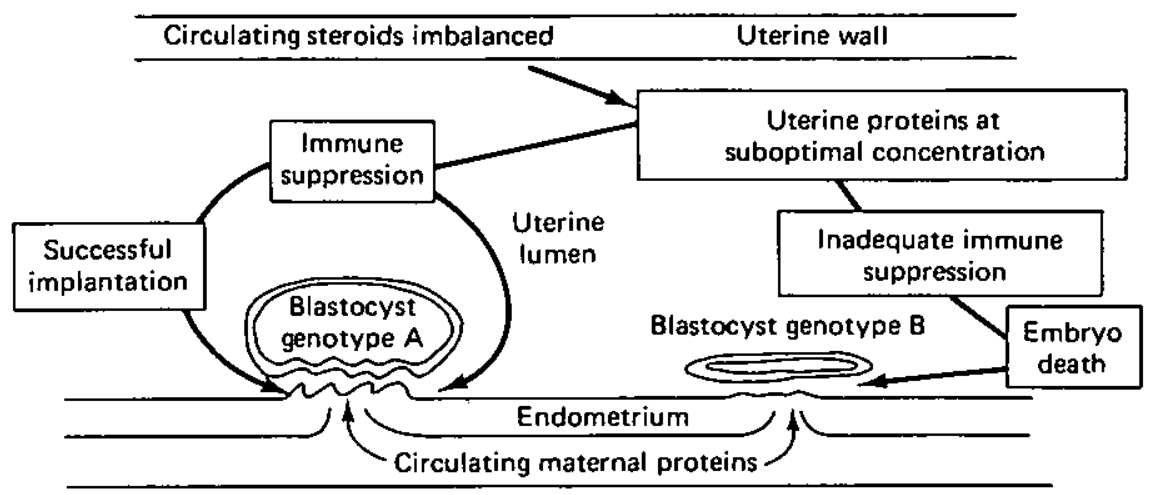

Figure 22.7 A schematic representation of embryonic death and its possible relationship with uterine environment

express themselves independently. Figure 22.7 shows a schematic representation of embryonic death and its possible relationship with uterine protein activity.

One of the progesterone induced uterine proteins has been identified as a 32000 dalton glycoprotein with a high iron content (Murray et al., 1972; Murray, Segerson and Brown, 1978). This has been named uteroferrin to add to the complexity of nomenclature (Bashe et al., 1980; Buhi et al., 1979). Bazer et al. (1975) have indicated that this protein appears to function in iron transport to the conceptus. Riboflavin has also recently been shown to be present in the uterus in significant amounts under the influence of progesterone in the pre-implantational stage (Murray et al., 1980). The precise role of this vitamin in embryonic nutrition, development and survival has yet to be evaluated.

The involvement of all of these substances in the expression of embryonic mortality seen in the early weaned sow would seem to be a fertile area for future studies.

\section{Uterine involution and endometrial repair}

Following parturition there is a decrease in the length and weight of the distended uterus (Palmer, Teague and Venzke, 1965a,b). This involution process is rapid the first week following farrowing and then proceeds more slowly until a minimum length and weight is attained by days $21-28$ of lactation. Degeneration of the endometrium is also seen during the first week of lactation, but by the end of the week regenerative processes are also evident and complete rebuilding of the endometrium may take place by days 14-21 post partum. Hence although complete involution does not occur until about three weeks into lactation it seems that much of the important rebuilding process has occurred by as early as day 7 post partum. From the evidence available there seems little reason why the uterus should not be fully competent again by 2-3 weeks post partum (Palmer, Teague and Venzke, 1965a,b; Graves et al., 1967; Svajgr et al., 
1974). This latter point is pertinent to the success or failure of very early weaning systems. If a sow is weaned at day 7 post partum and is remated thereafter at day 15 post partum, then fertilized eggs will appear in the uterus at about day 18 post partum. They may then be subject to an adverse uterine environment and will suffer accordingly.

Suckled sows show a faster rate of involution than sows which have had their litters removed early in lactation (Graves et al., 1967). Smidt, Thume and Jochle (1969), however, have noted that a quicker regeneration of the uterine gland itself takes place in sows which have been weaned compared with sows which have been suckled.

Although the uterine glandular capacity appears histologically competent within about 15 days post partum (Svagjr et al., 1974), the question not yet resolved is: how responsive are the uterine target cells and receptor systems to the steroid hormones for the production of the proteins mentioned above?

It might be that the interactions between plasma steroids, endometrial competence and uterine protein production may be responsible for the degree of embryonic survival observed in the very early weaned sow. They may also explain why in sows weaned after conventional lactation lengths embryonic mortality is still, on average, 25-30\% (Wrathall, 1971).

\section{Weaning at birth}

Systems of weaning at or near to the moment of birth have been investigated by a number of authors (Alexander, 1969; Braude et al., 1970; Robertson et al., 1971; Sharman et al., 1971; Jones, 1972; Tate, 1974). The advantage of weaning at birth rather than later at 7-10 days is that the high percentage of neonatal death which occurs in any system involving piglets suckling the sow is avoided. Much of the early work on weaning at birth has explored the nutritional requirements of the young piglets (Alexander, 1969; Braude and Newport, 1973; Braude, Keal and Newport, 1976, 1977; Tate, 1974; Newport, Storry and Tuckley, 1979). Difficulty has always been experienced in avoiding excessive scouring. Alexander (1969) observed clinical enteritis in $50 \%$ of piglets weaned at two days of age and $20 \%$ of all piglets scoured and $18 \%$ died following weaning at between two and four days. Williams (1976) has attributed this magnitude of loss to primary infection of piglets with rotavirus followed by colibacillosis. Considering the difficulties encountered with the young piglets it is not surprising that little attention has been paid to the reproduction of the sow following weaning at birth.

However, a recent paper (Elliot, King and Robertson, 1980) has described the subsequent reproductive performance of sows weaned at birth. Based on plasma progesterone analysis, these sows ovulated on average at $17.0 \pm 6.6$ days post partum but showed a significantly increased incidence of cystic ovaries compared to control sows weaned at 30 days post partum. Most of the sows weaned at birth exhibited nymphomania for the first two weeks post partum. The farrowing to effective service interval was $34.9 \pm 4.0$ days for control sows and $42.4 \pm 26.2$ days for sows weaned at birth. Weaning at birth was not associated with improved sow productivity 
and the overall farrowing interval for sows weaned at birth was 159 days compared to 148 days for the sows weaned at 30 days post partum. Clearly the sow weaned at birth experiences very serious endocrine disturbances.

In the spring of 1980 a unit was commissioned at the Rowett Research Institute to examine in detail both the sow's reproductive potential and the nutrition and immune development of piglets weaned at birth. The facility includes incubators for 96 piglets and flat deck accommodation to house piglets up to eight weeks of age as well as space for a self-contained herd of 24 sows and two boars. Under these conditions where the unit has been conceived, designed and built specifically for the purpose it is used, early results have shown that piglet mortality up to eight weeks can be reduced to under $5 \%$ with a low incidence of enteric disorders. The philosophy and concept behind this project has been described by Fowler and Varley (1981).

Currently in this unit the use of a new oral progestagen (Regumate; allyl trenbolone, Hoechst, UK) is being examined as a hypophyseal blocking agent for sows weaned at birth. This steroid is given for seven days from parturition and early results indicate that oestrus and ovulation will occur at day 14 post partum. This implies the possibility of a high order of sow reproductive performance. Fertility levels however have yet to be assessed.

\section{Practical considerations}

The sow weaned following a conventional long lactation length will show oestrus and ovulation rapidly and consistently after weaning. Although some losses of fertilized eggs occur, the eventual litter size will be large, particularly for sows in the third parity or above. By imposing a much reduced lactation period on the sow there is significant gain in terms of the number of litters produced per sow per year but there is also a loss in terms of the number of piglets per litter at each farrowing due to the effects reviewed in this Chapter. How much is gained or lost for each given lactation length has been assessed by Varley and Cole (1978) who concluded that as lactation length is reduced from the conventional 6-8 weeks down to about three weeks, there is a general increase in the annual sow productivity due to improving farrowing interval.

For lactation lengths much below three weeks any further improvement in farrowing interval is far outweighed by the reduced litter size and hence annual sow productivity falls. This conclusion is substantiated by the reports of Smidt, Scheven and Steinbach (1965) and Aumaitre, Perez and Chauvel (1975) illustrated in Figure 22.8.

Producers aiming to maximize sow productivity should consider the 3-week weaning system carefully. Many still take the view that 5-week weaning offers the maximum potential, although survey work (MLC, 1979; Ridgeon, 1979) consistently comes out in favour of 3-week weaning. The biological relationships described in this chapter also point emphatically to the conclusion that although the 3-week weaning system represents the interface between conventional and very early weaning systems at present it has more potential than any other system. The 3-week weaned sow can 


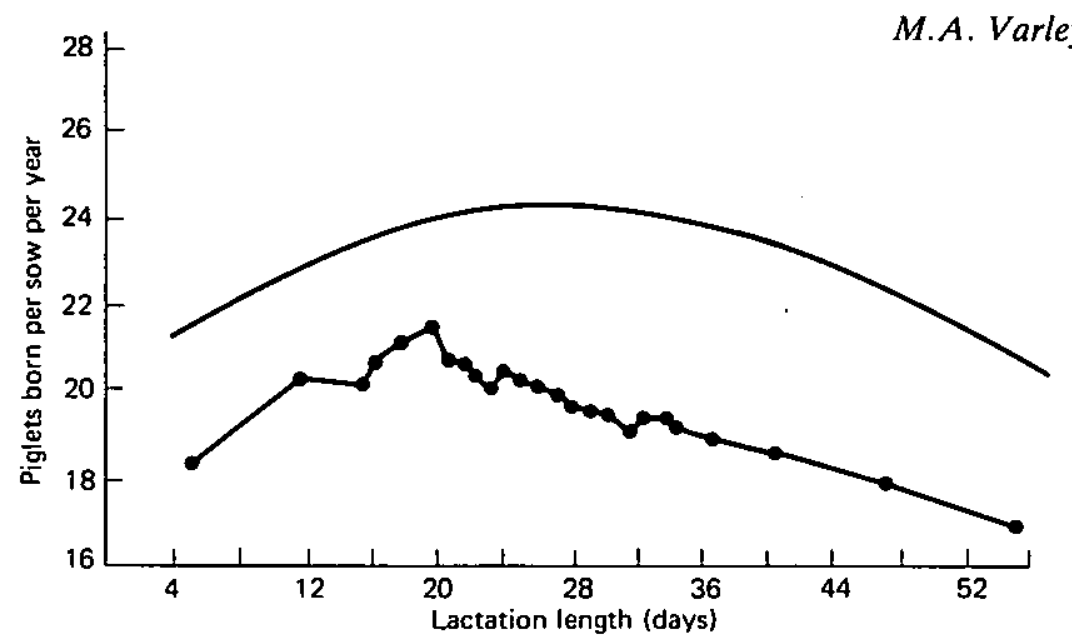

Figure 22.8 The effect of lactation length on annual sow productivity. Upper curve from Smidt, Scheven and Steinbach (1965), lower curve from Aumaitre, Perez and Chauvel (1975)

experience slightly increased embryonic mortality and Varley (1979) who has reviewed survey data on the prolificacy of these sows concluded that despite an apparent drop in average litter size of 0.2 piglets, the annual sow productivity from 3-week weaned sows can still be greater than other systems. te Brake (1976) has also carried out a comprehensive analysis of available data on this point. He concluded that 'weaning of piglets at 21-25 days of age is the most profitable way of producing piglets of $20 \mathrm{~kg}$ body weight'.

Part of the discrepancy in performance between farms may result from the age/parity effects reported by Walker et al. (1979). In a herd operating quite rapid generation turnover (for genetic improvement), the average age and parity of sows would be low. Little difference would therefore be detectable between 3-week weaning and 5-week weaning. On the other hand if a herd had a slow generation turnover and low sow culling rates the mean age and parity would be greater and therefore the effects of higher embryo mortality in the 3-week weaned sows would manifest itself as a very distinct difference in litter size compared with sows weaned at five weeks.

Looking to the future, with further work on the understanding of factors controlling embryonic mortality a highly productive 10-day weaning system can be envisaged producing around 26-28 piglets per sow per year. Alternatively by using the existing knowledge on the early induction of puberty and gestation in once bred gilts destined for meat production, coupled with weaning at birth, we may circumvent any problems of the sow's future reproductvve capacity and at the same time reduce neonatal death to a minimum.

\section{References}

ALEXANDER, V.A. (1969). Studies on the nutrition of the neonatal pig. PhD Thesis. University of Edinburgh AUMAITRE, A. (1972). Influence de mode de sevrage sur la productivité des truies. 23rd Annual Meeting E.A.A.P. Pig Commission, Verona 
AUMAITRE, A. and RETTIGLIATI, J. (1972). Age au sevrage chez le porcelet: Repercussion sur la productivite des truies et influence sur les jeunes animaux. Annls Zootech. 21, 634-635

AUMAITRE, A., PEREZ, J.M. and CHAUVEL, J. (1975). Effet de l'habitat et de l'age au sevrage sur les composentres de la productivité des truies en France. Journées de la recherche porcine en France, pp. 52-67. Paris, L'Institut Technique du Porc

BASHE, S.M., BAZER, F.W., GEISERT, R.D. and ROBERTS, R.M. (1980). Progesterone-induced uterine secretions in pigs. Recovery from pseudopregnant and unilaterally pregnant gilts. J. Anim. Sci. 50, 113-123

BAZER, F.W., ROBINSON, O.W., CLAWSON, A.J. and ULBERG, L.C. (1969). Uterine capacity at two stages of gestation in gilts following embryo superinduction. J. Anim. Sci. 29, 30-34

BAZER, F.W., CHEN, T.T., KNIGHT, J.W., SCHLOSNAGLE, D.C., BALDWIN, N.J. and ROBERTS, R.M. (1975). Presence of a progesterone-induced, uterine specific, acid phosphatase in allantoic fluid of gilts. J. Anim. Sci. 41, 112

BEIER, H.M. (1969). Endometrial secretion proteins-biochemistry and biological significance. In The Biology of the Fluids of the Female Genital Tract, (F.K. Beller and G.F.B. Schumacher, Eds.), pp. 89-113. Amsterdam, Elsevier

BEIER, H.M. and MAURER, R.R. (1975). Uteroglobin and other proteins in rabbit blastocyst fluid after development in vivo and in vitro. Cell Tiss. Res. 159, 1-10

TE BRAKE, J.H.A. (1972). Pig rearing in cages-the extra early weaning of piglets and the fertility of sows. 23 rd Annual Meeting E.A.A.P. Commission on Pig Production, Verona

TE BRAKE, J.H.A. (1976). An assessment of the most profitable lactation length for producing piglets of $20 \mathrm{~kg}$ body weight. $27 \mathrm{th}$ Annual Meeting E.A.A.P. Pig Commission, Zurich

BRAUDE, R. and NEWPORT, M.J. (1973). Artificial rearing of pigs. 4. The replacement of butterfat in a whole-milk diet by either beef tallow, coconut oil or soya-bean oil. Br. J. Nutr. 29, 447-455

BRAUDE, R., KEAL, H.D. and NEWPORT, M.J. (1976). Artificial rearing of pigs. 5. The effect of different proportions of beef tallow or soya bean oil and dried skim milk in the diet on growth, feed utilisation, apparent digestibility and carcass composition. Br. J. Nutr. 35, 253-258

BRAUDE, R., KEAL, H.D. and NEWPORT, M.J. (1977). Artificial rearing of pigs. 6 . The effect of different levels of fat, protein and methionine in a milk substitute diet containing skim milk and soya-bean oil. Br. J. Nutr. 37, 187-194

BRAUDE, R., MITCHELL, K.G., NEWPORT, M.J. and PORTER, J.W.G. (1970). Artificial rearing of pigs. 1. Effect of frequency and level of feeding on performance and digestion of milk proteins. Br. J. Nutr. 24, 501

BROOKS, P.H., COLE, D.J.A., ROWLINSON, P., CROXON, V.J. and LUSCOMBE, J.R. (1975). Studies in sow reproduction. 3. The effect of nutrition between weaning and remating on the reproductive performance of multiparous sows. Anim. Prod. 20, 407-412

BUHI, W., BAZER, F.W., DVCSAY, C.D., CHUN, P.W. and ROBERTS, R.M. (1979). Iron content, molecular weight and possible function of the progesterone-induced purple glycoprotein of the porcine.uterus. Fed.Proc. 38, 733

CLARK, J.R., DAILEY, R.A., FIRST, N.L., CHAPMAN, A.B. and CASIDA, L.E. 
(1972). Effect of feed level and parity on ovulation rate in three genetic groups of swine. J. Anim. Sci. 35, 1216

COLE, D.J.A., VARLEY, M.A. and HUGHES, P.E. (1975). Studies in sow reproduction. 2. The effect of lactation length on the subsequent reproductive performance of the sow. Anim. Prod. 20, 401-406

CRIGHTON, D.B. (1967). Effects of lactation on the pituitary gonadotrophins of the sow. In Reproduction in the Female Mammal, (G.E. Lamming and E.C. Amoroso, Eds.), pp. 228-238. London, Butterworths

DAY, B.M. and POLGE, C. (1968). Effects of progesterone on fertilisation and egg transport in the pig. J. Reprod. Fert. 17, 227-230

DYRENDAHL, S., OLSSON, B., FJORCK, G. and EHLERS, T. (1958). Artificial rearing of baby pigs. Part II: Additional experiments including the effect of early weaning on the fertility of sows. Acta agric. scand. 8, 3-19

ELLIOT, J.I. KING, G.J. and ROBERTSON, H.A. (1980). Reproductive performance of the sow subsequent to weaning piglets at birth. Can. J. Anim. Sci. 60, 65-71

ETZEL, B.J., MURRAY, F.A., GRIFO, A. P. Jr. and KINDER, J.E. (1978). Partial purification of uterine secretory protein capable of suppressing lymphocyte reactivity in vitro. Theriogenology 10, 469-480

FOWLER, V.R. and VARLEY, M.A. (1981). Recent development in weaning at birth. Proc. Pig Vet. Soc. (in press).

GRAVES, W.E. LAUDERDALE, J.W., KIRKPATRICK, R.L., FIRST, N.L. and CASIDA, L.E. (1967). Tissue changes in the involuting uterus of the post partum sow. J. Anim. Sci. 26, 365-369

HAY, D.M., FORRESTER, P.I., HANCOCK, R.L. and LORSCHEIDER, F.L. (1976). Maternal serum alpha-fetoprotein in normal pregnancy. Br. J. Obstet. Gynaec. 83, 534-538

HUGHES, P.E. and VARLEY, M.A. (1980). Reproduction in the Pig. London, Butterworths

JONES, A.S. (1972). Problems of nutrition and management of early weaned piglets. Proc. Br. Soc. Anim. Prod. 19-32

KIRKPATRICK, R.L. LAUDERDALE, J.W., FIRST, N.L., HAUSER, E.R. and CASIDA, L.E. (1965). Ovarian and pituitary gland changes in post partum sows treated with FSH. J. Anim. Sci. 24, 1104-1106

KLOPPER, A. (1979). The new placental proteins. Biol. Med. 1, 89-104

KNIGHT, J.W., BAZER, F.W. and WALLACE, H.D. (1974). Effect of progesterone induced increase in uterine secretory activity on development of the porcine conceptus. J. Anim. Sci. 39, 743-746

KNIGHT, J.W., BAZER, F.W., WALLACE, H.D. and WILCOX, C.J. (1974). Dose response relationships between exogenous progesterone and oestradiol and porcine uterine protein secretions. J. Anim. Sci. 39, 747-751

KNOBIL, E. (1980). The neuroendocrine control of the menstrual cycle. Recent Prog. Horm. Res. 36, 53-88

KRISHNAN, R.S. and DANIEL, J.C. Jr. (1967). "Blastokinin": Inducer and regulator of blastocyst development in the rabbit uterus. Science 158, $490-498$

LAI, P.C.W., MEARS, G.J., VAN PETTEN, G.R., HAY, D.M. and LORSCHEIDER, F.L. (1978). Fetal-maternal distribution of ovine alpha-fetoprotein. Am. J. Physiol. 235, E27-31 
LAUDERDALE, J.W., KIRKPATRICK, R.L., FIRST, N.L., HAUSER, E.R. and CASIDA, L.E. (1963). Some changes in the reproductive organs of the periparturient sow. J. Anim. Sci. 22, 1138

LOOKER, M. (1974). Cage rearing on a large scale. Pig Fmg 22, 66-67

MCINTYRE, J.A. and FAULK, W.P. (1979). Trophoblast modulation of maternal allogeneic recognition. Proc. natn. Acad. Sci. USA 76, 4029-4032

MLC (1979). Pig Improvement Services. Meat and Livestock Commission, Pig Feed Recording Services, 1979

MOODY, N.W. and SPEER, V.C. (1971). Factors affecting sow farrowing interval. J. Anim. Sci. 32, 510-514

MURGITA, R.A. and TOMASI, T.B. Jr. (1975). Suppression of the immune response by $\alpha$-fetoprotein. 1 . The effect of mouse $\alpha$-fetoprotein on the primary and secondary antibody response. J. exp. Med. 114, 269-286

MURRAY, F.A. and GRIFO, A.P. Jr. (1976). Development of the capacity to secrete progesterone-induced protein by the porcine uterus. Biol. Reprod. $15,620-625$

MURRAY, F.A., MOFFATT, R.J. and GRIFO, A.P. Jnr. (1980). Secretion of riboflavin by the porcine uterus. J. Anim. Sci. 50, 926-927

MURRAY, F.A., SEGERSON, E.C. and BROWN, F.T. (1978). Suppression of lymphocytes in vitro by porcine uterine secretory protein. Biol. Reprod. 19, $15-25$

MURRAY, F.A., BAZER, F.W., WALLACE, H.D. and WARNICK, A.C. (1972). Quantitative and qualitative variation in the secretion of protein by the porcine uterus during the estrous cycle. Biol. Reprod. 7, 314-320

NEWPORT, M.J., STORRY, J.E. and TUCKLEY, B. (1979). Artificial rearing of pigs. 7. Medium chain triglycerides as a dietary source of energy and their effect on liveweight gain, feed:gain ratio, carcass composition and blood lipids. Br. J. Nutr. 41, 85-93

PALMER, W.M., TEAGUE, H.S. and VENZKE, W.G. (1965a). Macroscopic observations on the reproductive tract of the sow during lactation and early post weaning. J. Anim. Sci. 24, 541-545

PALMER, W.M., TEAGUe, H.S. and VENZKE, W.G. (1965b). Histological changes in the reproductive tract of the sow during lactation and early post weaning. J. Anim. Sci. 24, 1117-1125

PARLOW, A.F., ANDERSON, L.L. and MELAMPY, R.M. (1964). Pituitary follicle stimulating hormone and luteinising hormone concentrations in relation to reproductive stages in the pig. Endocrinology 75, 365-376

PAY, M.G. (1973). The effect of short lactations on the productivity of sows. Vet. Rec. 92, 255-259

PETERS, J.B., SHORT, R.E., FIRST, N.L. and CASIDA, L.E. (1969). Attempts to induce fertility in post partum sows. J. Anim. Sci. 29, 20-24

POLGE, C. (1972). Reproductive physiology in the pig with special reference to early weaning. Proc. Br. Soc. Anim. Prod. 1972, pp. 5-18

PUY AOAN, R.B. and CASTILlo, L.S. (1963). A study on the effects of weaning pigs at different ages and the subsequent reproductive performance of their dams. Philipp. Agric. 47, 32-44

RIDGEON, R.F. (1979). Pig Management Scheme, Results for 1979, Agricultural Economics Unit, University of Cambridge

ROBERTS, G.P. (1977). Inhibition of lymphocyte stimulation by bovine uterine proteins. J. Reprod. Fert. 50, 337-339

ROBERTSON, V.A.W., JONES, A.S., FULLER, M.F. and ELSLEY, F.W.H. (1971). 
A pig herd established by hysterectomy. 1. The techniques for rearing hysterectomy derived piglets to 5 weeks of age. Res. vet. Sci. 12, 59-64 ROWLINSON, P. and BRYANT, M.J. (1974). Sows mated during lactation: Observations from a commercial unit. Proc. Br. Soc. Anim. Prod. 3, 93 SELF, H.L. and GRUMMER, R.H. (1958). The rate and economy of pig gains and the reproductive behaviour in sows when litters are weaned at 10 days, 21 days or 56 days of age. J. Anim. Sci. 17, 862-868

SHARMAN, G.A.M., JONES, A.S., DENERLEY, H. and ELSLEY, F.W.H. (1971). A pig herd established by hysterectomy. II. Health and performance. Res. vet. Sci. 12, 65-73

SMIDT, D., SCHEVEN, B. and STEINBACH, J. (1965). The influence of lactation on the sexual function of sows. Zuchtungskunde 37, 23-36

SMIDT, D., THUME, O. and JOCHLE, w. (1969). Investigations on post partum sexual regeneration in suckling and non lactating sows. Zuchtungskunde 41, 36-45

SMITH, D.M. (1961). The effect of daily separation of sows from their litters upon milk yield, creep intake and energetic efficiency. N.Z. J. agric. Res. 4, 232-245

SMITH, K.M., LAI, P.C.W., ROBERTSON, H.A., CHURCH, R.B. and LORSCHEIDER, F.L. (1979). Distribution of alpha-fetoprotein in fetal plasma, allantoic fluid, amniotic fluid and maternal plasma of cows. J. Reprod. Fert. 57, 235-238

SVAJGR, A.J., HAYS, V.W., CROMWELL, G.L. and DUTT, R.H. (1974). Effect of lactation duration on reproductive performance of sows. J. Anim. Sci. 38, 100-105

TATE, M. (1974). Studies on the utilisation of amino acids by the neonatal pig. $\mathrm{PhD}$ Thesis. University of Aberdeen

VAN DER HEYDE, H. (1972). A practical assessment of early weaning. Proc. Br. Soc. Anim. Prod. 33-36

VARLEY, M.A. (1976). Reproductive performance of the early weaned sow. PhD Thesis. University of Nottingham

VARLEY, M.A. (1979). Three week weaning and prolificacy. Pig Fmg 27, 34-35

VARLEY, M.A. and COLE, D.J.A. (1976a). Studies in sow reproduction. 4. The effect of level of feeding in lactation and during the interval from weaning to remating on the subsequent reproductive performance of the early weaned sow. Anim. Prod. 22, 71-77

VARLEY, M.A. and COLE, D.J.A. (1976b). Studies in sow reproduction. 5. The effect of lactation length of the sow on the subsequent embryonic development. Anim. Prod. 22, 79-85

VARLEY, M.A. and COLE, D.J.A. (1978). Studies in sow reproduction. 6. The effect of lactation length on pre-implantation losses. Anim. Prod. 27, 209-214

VARLEY, M.A., ATKINSON, T. and ROSS, L.N. (1981). The effect of lactation length on the circulating concentrations of progesterone and oestradiol in the early weaned sow. Theriogenology 16, 179-184

WALKER, N., WATT, D., MacLEOD, A.S., JOHNSON, C.L., BOAZ, T.G. and CALDER, A.F.C. (1979). The effect of weaning at 10,25 or 40 days on the reproductive performance of sows from the first to the fifth parity. $J$. agric. Sci., Camb. 42, 449-456 
478 The time of weaning and its effects on reproductive function

WILLIAMS, I.H. (1976). Nutrition of the young pig in relation to body composition. PhD Thesis. University of Melbourne

WRATHALl, A.E. (1971). Prenatal survival in pigs. Part I. Slough, England, Commonwealth Agricultural Bureaux 